\title{
The Brazilian deindustrialization: financialization is not guilty
}

MYLÈNE GAULARD*

RESUMO: A financeirização da economia brasileira é frequentemente criticada como sendo responsável pela desaceleração da acumulação de capital no país. Na verdade, muito altas taxas de juros são mantidas a fim de financiar a dívida pública, o que fomenta capitalistas para conseguir mais títulos do Tesouro em vez de investir na área produtiva. No entanto, a evolução da taxa de lucro nesta área também explica a relação especial existente entre os capitalistas, finanças e investimento produtivo, como mostrou Marx mais de um século atrás. PALAVRAS-CHAVE: investimento; finanças; lucro; desindustrialização ; Brasil.

ABSTRACT: The financialization of the Brazilian economy is often criticized as being responsible of the slowdown of capital accumulation in this country. Indeed, very high interest rates are maintained in order to finance the public debt, and this fosters capitalists to get more Treasury bonds rather than to invest in the productive area. Nevertheless, the evolution of the profit rate in this area also explains the particular relation existing between capitalists, finance and productive investment, as Marx showed it more than a century ago. KEYWORDS: investment; finance; profit; deindustrialization; Brazil.

JEL Classification: E11; E22; N16.

\section{INTRODUCTION}

In order to better understand the capitalist system, it is essential to wonder about the financialization of our economies. For instance, Brazil is confronted with such a situation since the beginning of the 1980s. Indeed, this financialization represents an exponential growth of incomes, due to the holding of different assets, which is caused by the very high interest rates observed in this country. In the Brazilian economic literature, it is often claimed that the financialization is responsible for the slowdown of accumulation, for the low level of gross fixed capital formation. However, the Brazilian financial income have had a decreasing evolution since the beginning of the

\footnotetext{
* Université Grenoble Alpes, France (CREG). E-mail: mylene.gaulard@gmail.com. Submetido: 14/ Maio/2013; Aprovado: 7/Julho/2014.
} 
$21^{\text {th }}$ century, and in spite of this evolution, the investment rate still remains very low. This, it is necessary to make a new hypothesis in order to explain the slowdown of accumulation. To fulfill this aim, Marx's theory of crisis will be very helpful.

\section{THE FINANCIALIZATION OF THE BRAZILIAN ECONOMY}

\section{A weak investment rate}

Graph 1: Rate of the Brazilian gross fixed capital formation (in \% of the GDP), at current and constant prices (1970-2007)

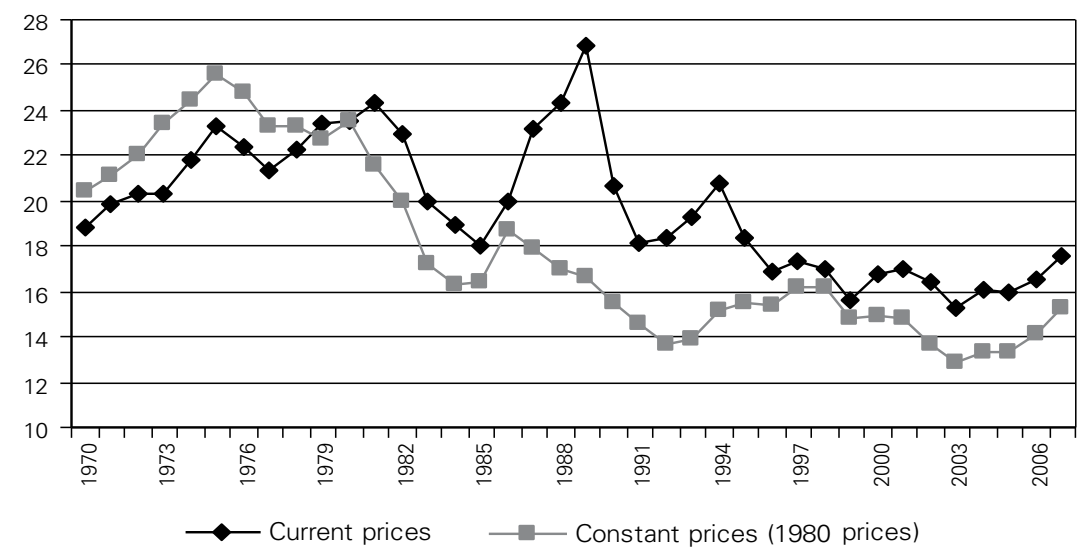

Source: IPEADATA, graph made by the author.

Since the "lost decade" of the 1980, Brazil is stigmatized for having a too low investment rate. This one stagnates between $15 \%$ and $18 \%$ of the GDP. The worst of it all is that, according to Aumara Feu (2004b) and the IEDI ${ }^{1}$ (2007), this stagnation is due to the rising cost of the fixed capital. Indeed, if constant prices (here the 1980 ones) are taken, the rate of gross fixed capital formation (GFCF) decreases, after a brief recovery from 1992 to 1997, since 1998 (from 16\% in 1998, to 13\% in 2004), after having plummeted from 1977 to 1991. Admittedly, since 2004, the GFCF rate (at current as well as at constant prices) is slightly increasing, but still remains lower than $20 \%$ in spite of this evolution.

This weakness of investment goes along with an important decrease of the industry's share in the value-added creation. The transformation industry represents less than $18 \%$ of the GDP in 2005 (against $41 \%$ in China), while this share was $32 \%$ in 1986 (IEDI, 2005). Brazil has entered into a process of deindustrialization, which can be observed in terms of its productive structure as well as its exports.

\footnotetext{
${ }^{1}$ Instituto de Estudos para o Desenvolvimento Industrial (“Studies Institute for Industrial Development”).
} 
While in 1994, the share of manufactured goods in total Brazilian merchandise exports was $57,3 \%$, nowadays this goods represent less than $50 \%$ of the exports.

This deindustrialization can also be evidenced by the breaking down of the fixed capital used each year. Indeed, fixed capital is not always productive capital taking part in the accumulation process: the GFCF rate also includes the residential investment and this one takes up a more and more important share (Graph 2). Furthermore, in 1979 , equipment goods represented $30 \%$ of the whole fixed capital, while this share is only $17 \%$ in 2004 (Bruno, 2006). There is a growing importance of residential and industrial construction. The GFCF rate which concerns the accumulation alone (essentially equipment goods) is therefore much lower than the one usually accepted.

Graph 2: Share of residential construction and equipment goods in the Brazilian fixed capital stock, in \% (1950-2007)

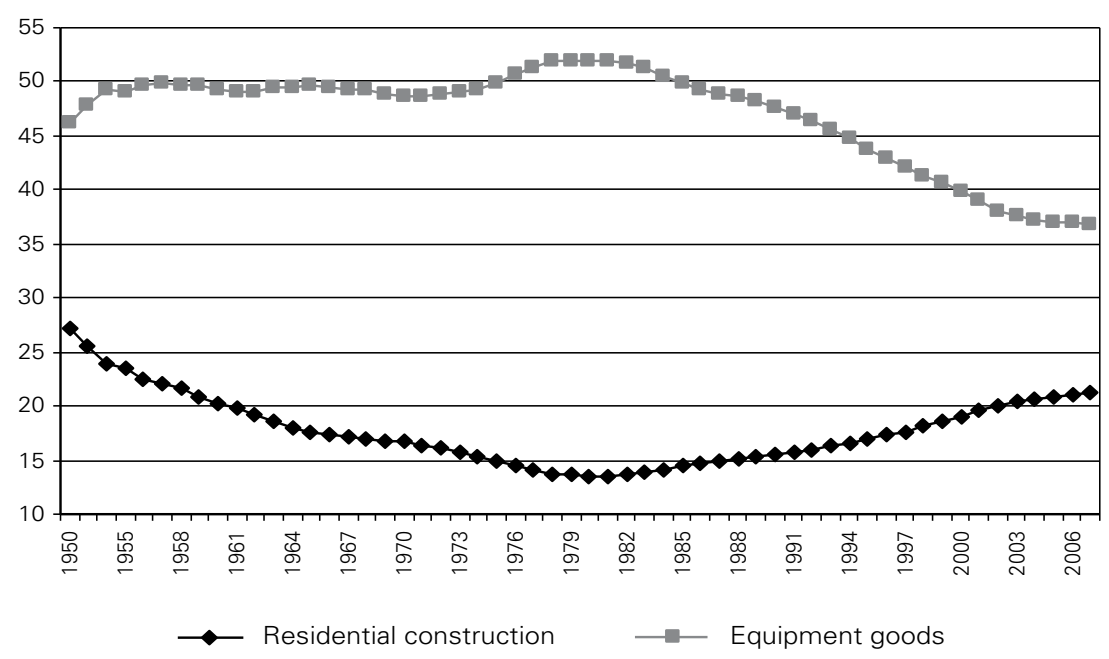

Source: IPEADATA, graph made by the author.

For a recent BNDES (the Brazilian development bank) report (Teixeira, 2007), the transformation industry and the national infrastructure represented $52 \%$ of the whole Brazilian investment during the 1970s, and in 2006, this share was only $29,6 \%$. The space left by these two economic "sectors" is now occupied by services which represented $9 \%$ of the GFCF in the 1970 s versus $30 \%$ nowadays. The residential construction also takes a major place, representing more than $20 \%$ of the GFCF.

Then, Brazil has a low accumulation rate, and this is usually explained by an analysis of the Brazilian financial sector. In fact, there would be a "financialization" process in this country. Rentiers would monopolize the national wealth thanks to very high interest rates, and would do so at the expense of productive accumulation. The financialization would thus be responsible for a stagnation of the investment rate. 


\section{The financialization of the economy}

According to Miguel Bruno (2005), the rentiers' incomes increase at the expense of the productive investment, and this would be due to the economic integration of Brazil into the "current globalization process". Benchmarking would impose in Brazil, for Bruno, very high interest rates ${ }^{2}$, and the increase of the debt burden would reduce the profits the productive investment gets. In fact, the Brazilian interest rates are among the highest in the world. The Selic, the major short-term interest rate, reaches $11 \%$ in October 2014.

The Brazilian economic policies explain the high level of the interest rates: the government tries to turn the foreign debt into internal debt, by making more attractive the Brazilian Treasury bonds. In order to pay back the external public debt, Treasury bonds are put into circulation, and they seem all the more interesting as the interest rates are high. This economic policy was experimented during the sixties in Brazil, when the Treasury bonds helped to create a middle class that could consume and buy a part of the idle production capacities.

Nowadays, the repayment of the public debt is allowed by the permanent circulation of bonds. So, this circulation is responsible for a strong increase of the Brazilian financial rent (the whole flow of shares and interests received by the Brazilian banking and financial system), and for a huge concentration of wealth. In 2005 , the five biggest Brazilian banks concentrated $70 \%$ of the profits of the national banking system (Boito Junior, 2006), and from 1994 to 2003, the ten major banks' profits have increased by $1039 \%$. In 2006, only 15000 households possessed $80 \%$ of the Treasury bonds, what perfectly reveals the wealth concentration due to this financialization (Pochmann, 2003).

According to Miguel Bruno (2005), this financialization of the economy would date back to the 1960s and 1970s; for instance, the Government Economic Action Program established in 1964 a new monetary procedure for indexing the financial assets' value to the inflation. This operation allowed to reduce financial losses, and to promote credit in view to increase investment and consumption during the 1960s "Economic Miracle". Moreover, at that time the public debt appeared necessary to sustain the accumulation process. If the public debt level is now so high, it is in reason of the role of the State during the post-war industrialization.

Indeed, the State played the role of the bourgeoisie, by stimulating the economic accumulation. In this country, the capitalist mode of production did not arise

\footnotetext{
${ }^{2}$ However, Bresser-Pereira (2007, p. 197) lays stress upon the fact that the evolution of the Brazilian interest rates does not even reflect the risk allowances for this country. Indeed, for more than ten years, these risk allowances have plummeted. Today, only the fear of inflation fosters the central Bank to maintain or to rise the interest rates (in June 2008, the short term rate increased from $11,75 \%$ to $12,25 \%$ because the inflation was forecasted to average $10 \%$ in 2008 , the highest level since 2005). Nonetheless, the fact remains that this fear could be considered as irrational because there were still no tensions on the production capacities and because the inflation was not due to an excessive demand. This evolution, observed in the whole world until the middle of 2008, was the result of the price increase of raw material, and this evolution could no be stopped by rising the interest rates.
} 
from the contradictions existing between productive forces and relations of production. So then, the bourgeoisie was not enough developed during the first steps of industrialization, and the State appeared essential to replace it. The accumulation was stimulated by the creation of national enterprises and by the State takeover of not very profitable enterprises. Cheap products were provided to national or foreign private firms, which encouraged the development of the Brazilian bourgeoisie.

The price of it was the external public debt increase, in particular during the 1970s. During those years, the oil-producing countries' incomes rocketed and were invested in Peripheral countries like Brazil. In fact, the accumulation of debt was due to capitalism's expansion in countries where the bourgeoisie was not enough developed. Furthermore, the required funds, in order to climb the industrial ladder and to catch up from the technological backwardness with the Center countries, were so huge that only an important external debt could be enough to stimulate the accumulation. The present financialization of the Brazilian economy is the result of the development of the capitalist mode of production in a time when the bourgeoisie was absent and when the Brazilian technological backwardness involved huge funds.

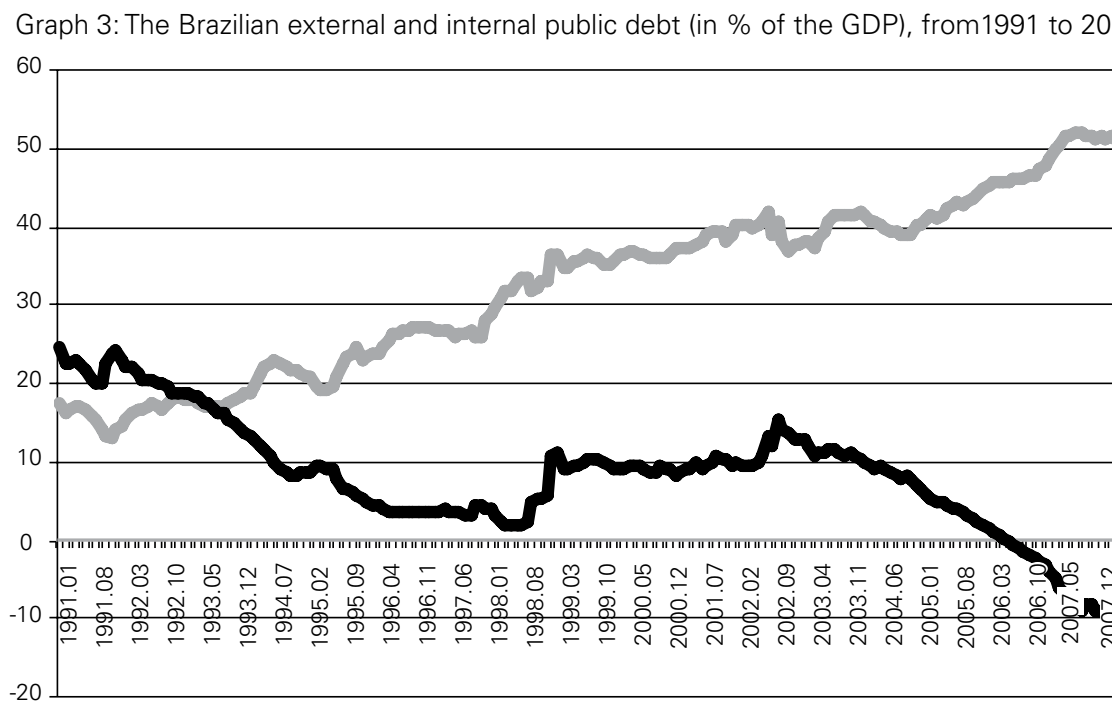

Internal public debt 2 External public debt

Source: IPEADATA, graph made by the author.

Since the crisis of the 1980s, this debt does not allow anymore to stimulate the capital accumulation, but it only serves to increase the richest incomes: the Brazilian public debt still increases, not for financing new investment but for paying debt service. High interest rates allow the richest Brazilians to increase their income thanks to Treasury bonds: while, for a long time, the country needed foreign funds, the present debt is principally internal, financed by national savings which are consequently no more available for financing productive investments. So then, in 
Brazil, the external public debt is turned into internal debt: the State does not finance itself on the international markets, but it regularly puts Treasury bonds into circulation. Nonetheless, the fact remains that these funds can also be provided by foreigners: they are borrowed from other countries by Brazilians or they directly come from foreign investors. The financialization of the Brazilian economy has its roots in the expansion of Treasury bonds.

The weight of finance evidently impacts on net profits and on productive investment. According to Reinaldo Gonçalves (2006), the high interest rates observed since 1995 take a major part in a mechanism transfer of incomes to the financial sector. The average investment rate, from 1980-1994 to 1995-2004, decreased from $21,3 \%$ to $19,3 \%$ of the GDP, while the average short-term interest rate rose from 3,8\% to $12,3 \%$. Because of these high interest rates, the profits received by financial institutions are realized at the expense of the profits remaining in the productive sector.

As the Graph 4 shows, the interest rate at which enterprises and households borrow is higher than $30 \%$. The bank-spread (difference between the bank's cost of funds and the rate the bank charges to debtors on bank loans) is higher than $20 \%$, which makes the credit extremely expensive. While the average profit rate of the finance capital decreased from 22,4\% between 1980 and 1994 to 19,4\% between 1995 and 2004 (a decrease of 13\%), the average profit rate of the productive capital ${ }^{3}$ decreased from $8,2 \%$ to $5,6 \%$ (a decrease of $32 \%$ ) between these two periods (Gonçalves, 2006). The falling rate of profit for the finance capital is lower than for the productive one. The high interest rates observed in Brazil impede investment, not only because they rise enterprises' debt burden but also by restraining credit supply: indeed, in 1976 the volume of credit represented $80 \%$ of the GDP against $30 \%$ in 2007 .

Graph 4: Average interest rate and bank-spread

for Brazilian households and enterprises (2006-2007)

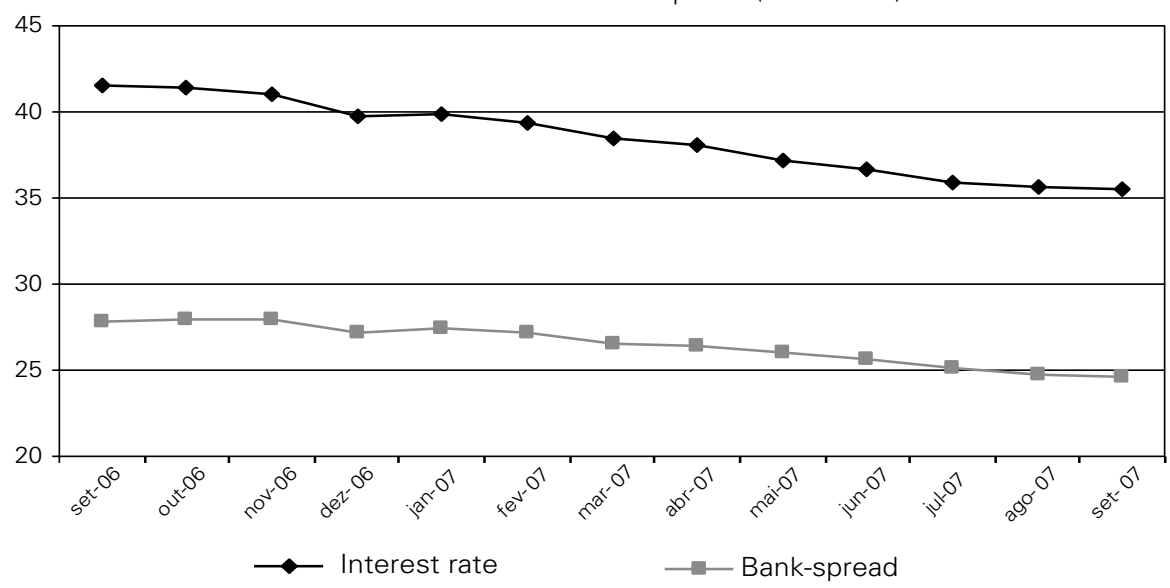

Source: Banco Central do Brasil, graph made by the author.

${ }^{3}$ The profit rate of productive capital here corresponds to the ratio of made net profits to equity capital. 
Table 1: Brazilian average interest rates for some bank operations

\begin{tabular}{|c|c|}
\hline & Average interest rate \\
\hline Special check & $149 \%$ \\
\hline Personal loans & $48 \%$ \\
\hline Car loans & $27 \%$ \\
\hline Other goods loans & $55 \%$ \\
\hline Average & $38 \%$ \\
\hline
\end{tabular}

Source: Banco Central do Brasil.

\section{Questioning the "thesis of financialization"}

Following this thesis, the low Brazilian investment rate could be explained by these too high interest rates. Today, the country would experiment an exceptional period of "financialization" of its economy because of a world expansion of financial markets (Bruno, 2005). However, Bruno's explanation only allows us to grasp the current situation, although Maria de Conceição Tavares already claimed in 1982 that "high interest rates go with an expansion of external debt and of Treasury bonds which are made more and more attractive for placing the idle funds of big enterprises and banks" (in Serra, 1982, p. 137). At the end of the 1970s, the Brazilian economy had to face with a slowdown of its investment rate because of these high interest rates. And this period was not yet characterized by a development of financial markets as important as nowadays...

Graph 5: Brazilian public debt interests, in \% of the GDP (2000-2008)

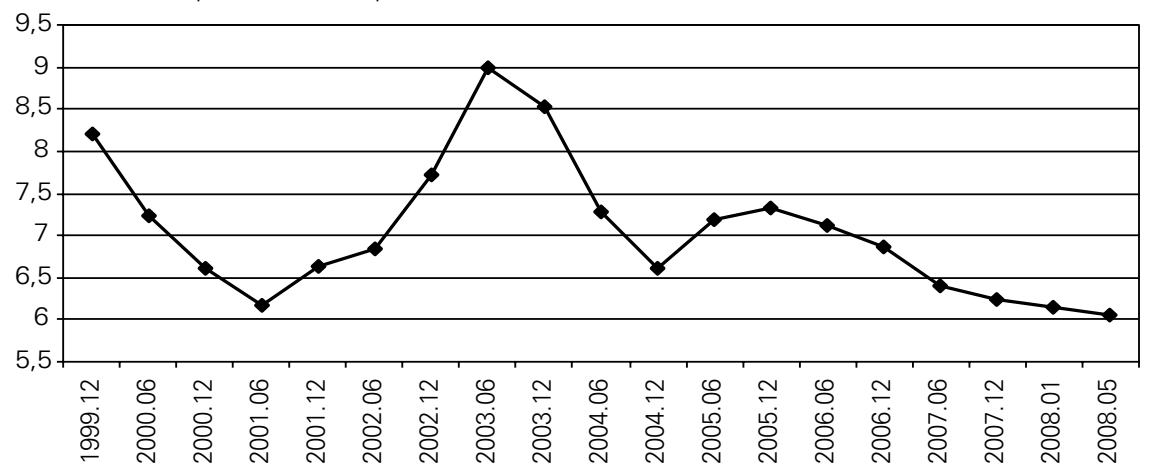

Source: Banco Central do Brasil, graph made by the author.

Furthermore, as the Graph 5 shows, the real interest rates are decreasing since 1998 (the real short-term interest rate decreases from $25 \%$ in 1998 to

\footnotetext{
${ }^{4}$ Translation by the author: "Conjugam-se aí taxas elevadas de juros com expansão da dívida externa, cujos títulos se tornam ainda mais atraentes como refúgio para os recursos ociosos das grandes empresas e dos bancos".
} 
$7,25 \%$ in 2008), and Miguel Bruno is unable to explain that. In fact, at the world level, the abundance of savings leads to very low interest rates. World savings have never been so huge. The increasing incomes of the oil-producing countries (due to the rise of oil prices), the excess savings of Asian countries (due to the slowdown of investment, except for China, since the 1997 crisis), and the low investment rate in the whole developed countries since the end of the 1970s, are responsible for these huge savings ${ }^{5}$. Today, these world savings particularly allow to finance the US debt and can also explain the unprecedented development of financial markets. In consequence, the financialization process can not be perfectly explained by the current high level of the interest rates in Brazil. On the contrary, the interest rates have never been so low since fifteen years, as well in this country as in the rest of the world.

The interests paid each year by the Brazilian State are decreasing since 2003 (from 8,99\% of the GDP in June 2003 to 6,06\% in May 2008). Evidently such an evolution can essentially be understood thanks to the fall of the short-term interest rate (the Selic), from $24 \%$ in 2003 to $11,25 \%$ in May 2009. It can be assumed that thanks to the rising rate of profit (which will be studied below) in productive sectors since 1995, the financiers are less demanding and more trustful; so, they invest more in the productive apparatus in reason of those increased profits.

Furthermore, the Brazilian credit is also rising since 2003, but this evolution is not accompanied by a reinforced accumulation. The gross fixed capital formation is still lower than $20 \%$ of the GDP although, as the Graph 7 shows, credit operations soar from $25 \%$ to $35 \%$ of the GDP between 2003 and 2008 .

Graph 6: Brazilian property earnings in \% of the gross national income (1997-2007)

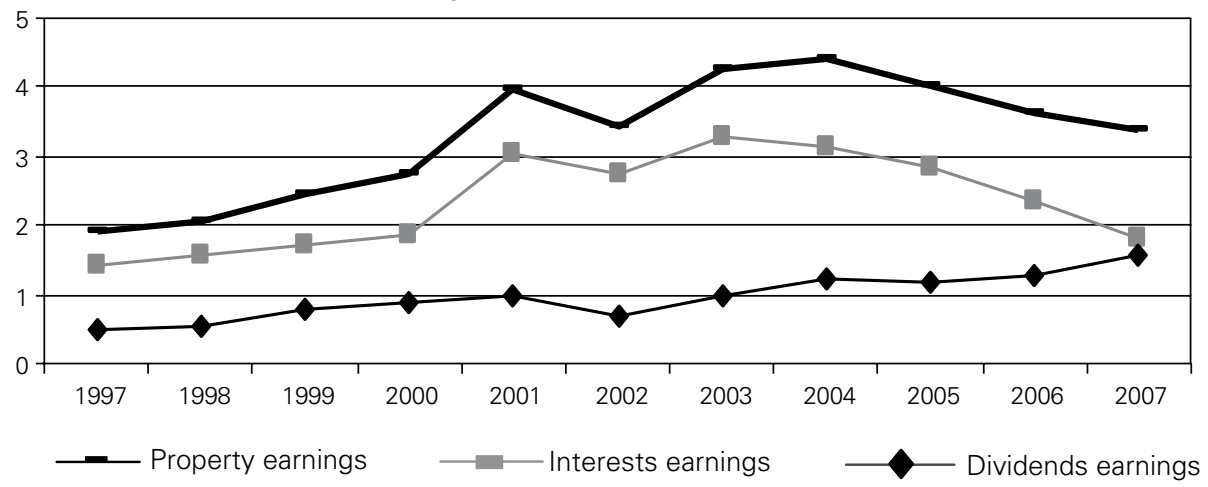

Source: IPEADATA, graph made by the author (interests and dividends remaining in the country).

\footnotetext{
${ }^{5}$ Brender et Pisani, Les déséquilibres internationaux, Repères, La Découverte, 2007.
} 
Graph 7: Brazilian credit operations in \% of the GDP (2000-2008)

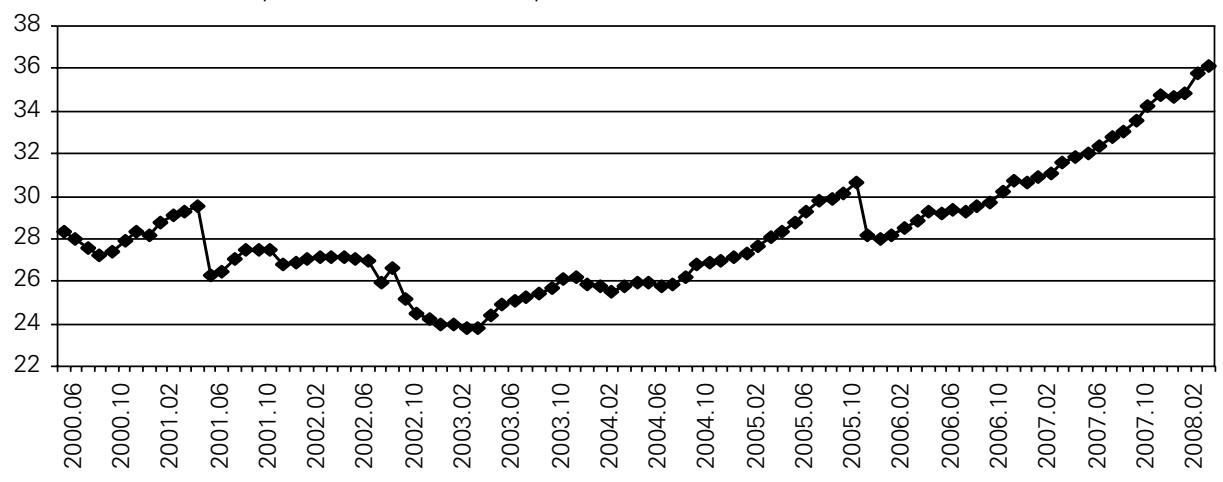

Source: IPEADATA, graph made by the author.

Thus, the investment rate remains low, in spite of the interest rates' decrease and of the rise of credit operations in Brazil's economy. The thesis of financialization does not seem to be a relevant explanation to understand better the slowdown of the accumulation process and the low investment rate observed in this country. These phenomenons cannot be grasped as mere consequences of the financial markets development and of the high interest rates. There is a link between the investment decrease and the rise of financial incomes, but it is not in this way: since the end of the 1990s, the interest rates have decreased in Brazil, but contrary to Bruno's thesis, this evolution did not boost the investment. The GFCF rate keeps stagnating (or even decreasing until 2004), and it will be showed that it is the reason why the finance sector is now booming.

There is indeed a financialization process in Brazil, but this process cannot be blamed for the slowdown of accumulation and for the deadlocks the productive apparatus is facing with. This phenomenon can also be observed in the Center countries. The financialization did not have its roots in Brazilian accumulation specificities, and it is important to go back to Marx's capitalism analysis to understand it better.

Until the end of the 1980s, another theory tried to show the link between finance and the fall of the investment rate, but in a different way. According to certain authors, the slowdown of investment had not its causes in the development of finance, but the decrease of investment incentives boosted the rise of finance. For Luiz de Mello Belluzzo (1982, p. 141), "faced with a falling rate of profit, forecasted for new productive investments, the mass of profit is directed towards financial and speculative investments which lead to more inflation" ${ }^{6}$

Therefore, in order to understand better the current situation, it is very impor-

\footnotetext{
${ }^{6}$ Translation by the autor: "Diante de uma queda esperada de lucro, para novos investimentos produtivos nos mesmos setores, sua massa de lucros é dirigida a aplicações financeiras e imobilizações de carácter especulátivo que, por seu turno, provocam uma alimentação de inflação.” However, this analysis is opposed to Belluzzo's present conclusions. This economist prefers to follow the ruling
} 
tant to study the evolution of the profit rate, which may be responsible for a stagnation of the gross fixed capital formation. Capitalists would prefer to channel their incomes to sectors more profitable than the productive one, which would explain the present development of finance. In fact, the Brazilian profit rate keeps decreasing from the end of the 1970s until 1994. By going back to a Marxist analysis, this fall of the profit rate will be explained by the capital productivity decrease observed since the end of the "Economic Miracle". This evolution of capital productivity leads to a falling rate of profit when there is at the same time a lesser rise of labor productivity.

Henryk Grossman's thesis (1979) will be used to explain the slowdown of accumulation. For him, the development of finance could be explained by a low profitability of industrial investments. The financial sector would be a new area to invest excedentary funds. Nowadays, many authors from the regulationist current are trying to make a distinction between a "good" and a "bad" capitalism (that is to say the "productive capitalism" and the "finance capitalism"). Nevertheless, by doing this, they only manage to hide the fact that the financialization of the capitalist economy is intrinsic to capitalism and is due to the inescapable tendency for the rate of profit to fall.

The financialization of the economy cannot be dissociated from capitalism. Many economists, Keynesian ones in particular, think that a decrease of the interest rates would boost the growth: according to Michel Husson (2001, p. 47), these authors are confusing the cause and the consequence of the crisis because the rise of the interest rates is an answer to the low profit rate of productive sectors. The falling rate of profit fosters the capitalists to invest more and more in the financial area.

\section{The evolution of the profit rate in Brazil}

In this part, it will be important to stress on the link existing between the theory of the falling rate of profit and the problems encountered by Brazil's investment nowadays. The data given by the Brazilian statistics offices are at so huge values and are so difficult to calculate, that it is undeniable that the obtained results are only approximations. Here, only the evolution matters. First, it will be showed that the organic composition of capital has kept on rising for two decades. Under certain conditions (more particularly if the organic composition increase is higher than the exploitation rate increase), such an evolution may weigh on the profit rate (corresponding to the following expression:

$(\mathrm{S} / \mathrm{V}) /((\mathrm{C} / \mathrm{V})+1)$, with $\mathrm{S} / \mathrm{V}$ as the exploitation rate and $\mathrm{C} / \mathrm{V}$ as the organic composition of capital: $\mathrm{S}$ as the surplus-value, $\mathrm{C}$ as the constant capital and $\mathrm{V}$ as the variable one. The analysis of the profit rate evolution in this country will help us to better understand the problems encountered by the accumulation process.

Keynesian thought in order to understand the current Brazilian situation (with an economic stagnation explained by too high interest rates). 


\section{Calculation of the profit rate}

To calculate this rate of profit which, according to Marx, corresponds to the expression $\mathrm{S} /(\mathrm{C}+\mathrm{V})$, we consider here that it is possible to take into account the data given by the Brazilian official statistics offices. However, for Marx, the profit rate is calculated with values and not with prices. Although it is pointless here to come back to the value/price Marxian debate, launched in the beginning of the $20^{\text {th }}$ century, the working hypothesis here is that the sum of prices is equal to the sum of values on a national scale. For this calculation, the debate on the transformation of values into prices will be put aside.

Concerning the used data, it is considered here that the GDP (minus the wages) corresponds the most with the Marxist surplus-value (for Marx, the production value corresponds to $\mathrm{S}+\mathrm{V}+\mathrm{C}$. Here, the GDP, the sum of valueadded, does not take into account intermediate consumption, which can be likened to $\mathrm{C}$, but it includes wages, which it is consequently necessary to subtract in order to obtain the surplus-value. Concerning the constant capital, we take the stock of fixed capital used during the process, from which residential investment is subtracted. Finally, the variable capital corresponds to the stock of wages. According to Marx, the variable capital corresponds to productive workers only; nevertheless, this distinction will not be done here because it is very difficult, from a statistical perspective, to differentiate productive and unproductive workers; moreover, the stock of wages is so weak compared to the stock of fixed capital, that subtracting the wages of unproductive workers would not significantly modify the results, and even less so the tendencies, which matter the most for this analysis.

\section{The capital productivity ${ }^{7}$ evolution}

The falling rate of profit cannot be analyzed without studying the capital and labor productivity. For the needs of this analysis, it is considered that the organic composition of capital corresponds to what is known as "capitalistic intensity". If the labor productivity increase is higher than the capital productivity one, then the organic composition

\footnotetext{
${ }^{7}$ It could be reproached us here that using the term "capital productivity" is not really relevant, because from a Marxist approach only workforce can create surplus value, and then only work is productive. However, for the needs of our analysis and keeping in mind the potential limitations, this criticism will be here disregarded. Moreover, while in Marx's work, constant capital corresponds to equipment goods and to raw materials (elements able to transmit their own value without creating value by their own), only the fixed capital (that is to say the means of production which are not destroyed during the production process and which life duration is higher than one year) will be taken into account here. Taking into account raw material would not change the results very much because this cost is insignificant compared to the equipment goods' cost. Furthermore, this would only strengthen our results because it would increase even more the organic composition of capital.
} 
of capital is rising, and reciprocally. To sum up, if S/V increase is higher than S/C increase, this implies that $\mathrm{C}$ increase is higher than $\mathrm{V}$ increase, and then $\mathrm{C} / \mathrm{V}$ is rising.

As the Graph 8 and 9 below show, the labor productivity (in value, that is to say the ratio of the realized value added, the GDP, to the stock of wages) has essentially periods of rise (except from 1950 to 1957, and from 1980 to 1990), while the capital productivity (ratio of the GDP to the fixed capital used in the production apparatus) keeps plummeting, except for the recent period when it begins to stagnate (and even to slightly increase) between 1990 and 2008, and during the "Economic Miracle" (from 1966 to 1974). In these conditions, it is logical that the organic composition of capital experiments a regular growth since 1950 . How to explain such a growth? Why does the capital productivity keep falling for such a long time? Traditional explanations will be first presented; then, it will be essential to go back to Marx's analysis.

\section{Graph 8: Labor productivity in Brazil (1950-2007)}

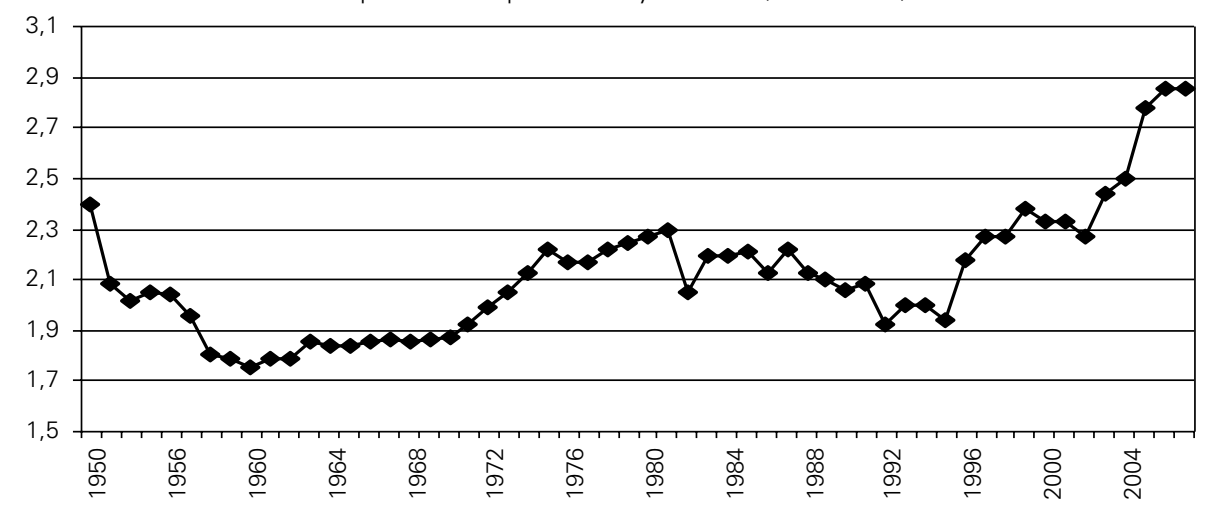

Source: IPEADATA (Labor productivity in value: GDP/Stock of wages), graph made by the author.

Graph 9: Capital productivity in Brazil (1950-2007)

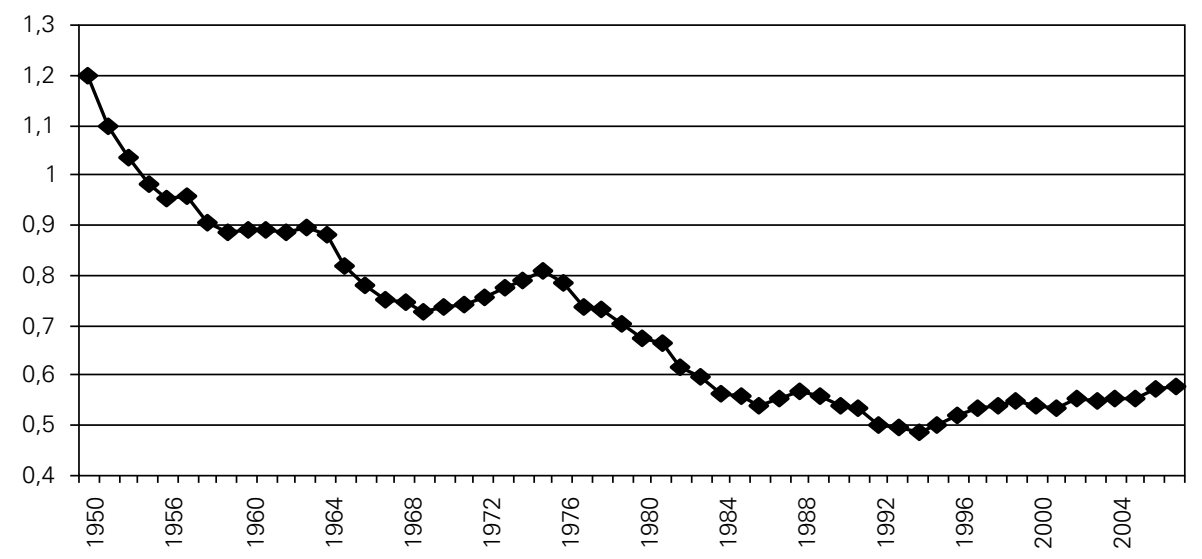

Source: IPEADATA (Capital productivity in value: GDP/Stock of wages), graph made by the author. 


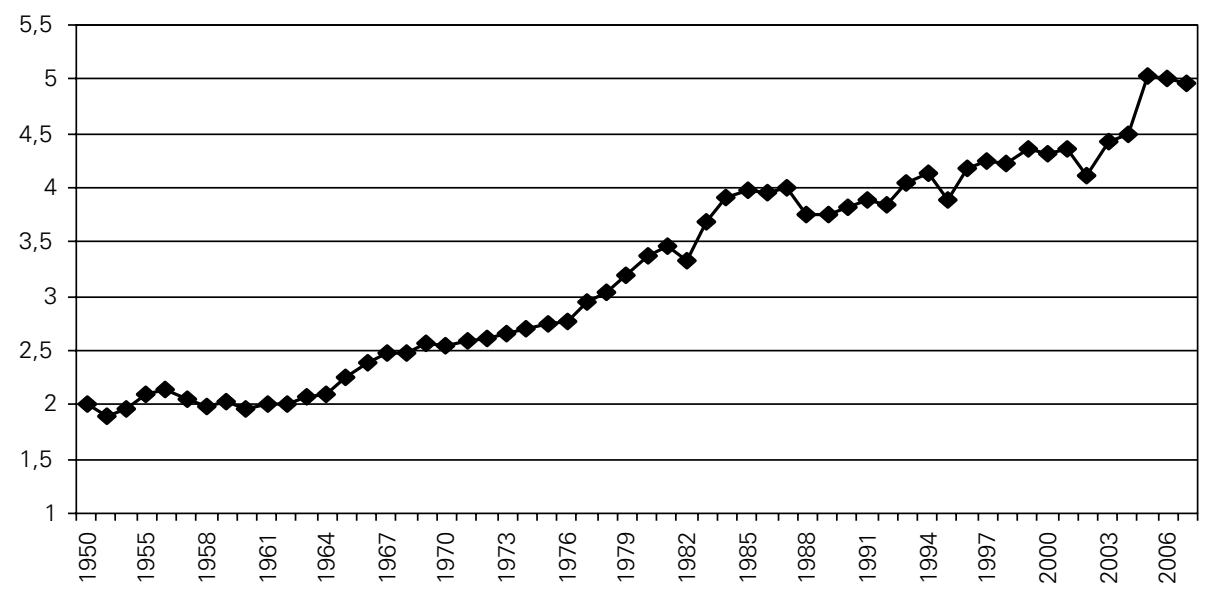

Source: IPEADATA (Organic composition of capital: Stock of fixed capital/Stock of wages), graph made by the author.

According to Regis Bonelli (2005), the growth of the relative price of investment, as well as the following decrease of the capital productivity, has their root in the inefficiency of the production process (particularly in the production of equipment goods) and in the rise of idle capacities. The inefficiency of the production apparatus would be responsible for a very strong growth of equipment goods prices.

Indeed, the price of investment ${ }^{8}$ keeps rising, and as it has been shown before, this evolution distorts the study of the gross fixed capital formation. The GFCF rate is not the same depending on whether current or constant prices are taken into account. For the IEDI (2007), equipment goods prices have never been so high, and such a situation evidently (according to Bonelli) leads to a fall of the capital productivity.

Nevertheless, the link existing between the capital productivity decrease and the equipment goods rising price is put into question by the recent evolution. Like us, Lucilene Morandi notices that there is a slight rise in capital productivity since the beginning of the 1990s. The explanation given by Morandi is that Brazil's currency appreciation helps rising the capital productivity thanks to cheaper equipment goods imports. The economic opening, as well as the rise of equipment goods imports, would remedy to the inefficiency of the national production apparatus. However, according to IEDI's works (2007), the equipment goods prices have never been so high, which throws Morandi's thesis back into doubt. The current capital productivity growth cannot be explained by the evolution of the investment price. This one has never been so important, although the country does not experiment for almost two decades a fall of its capital productivity.

\footnotetext{
${ }^{8}$ Ratio between the prices of infrastructure and equipment goods used by the production apparatus and the prices of consumption goods.
} 


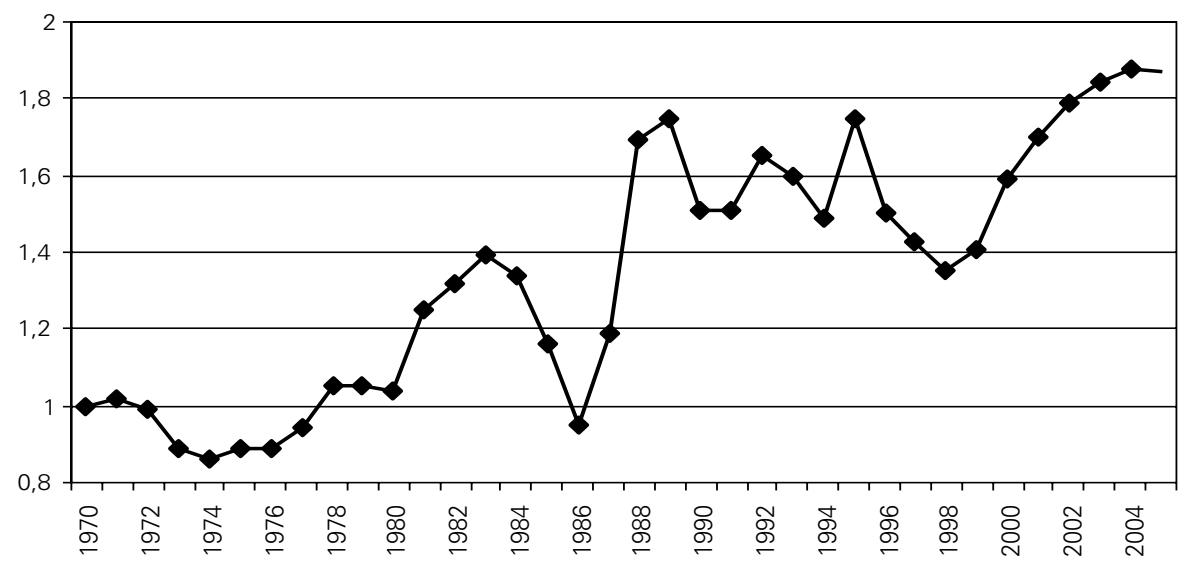

Source: IEDI (2007), graph made by the author.

It is essential to find another explanation to the recent rise of the capital productivity. According to Aumara Feu (2004a), this rise has its roots in the slowdown of accumulation. Indeed, the slowdown means that the capitalists do not replace their equipment goods, and by doing so, they limit fixed capital increase. This behavior leads to a lesser rise of value-added and overall to a more important growth of the capital productivity: in the capital productivity formula, the denominator (stock of fixed capital) increases slower than the numerator (value-added).

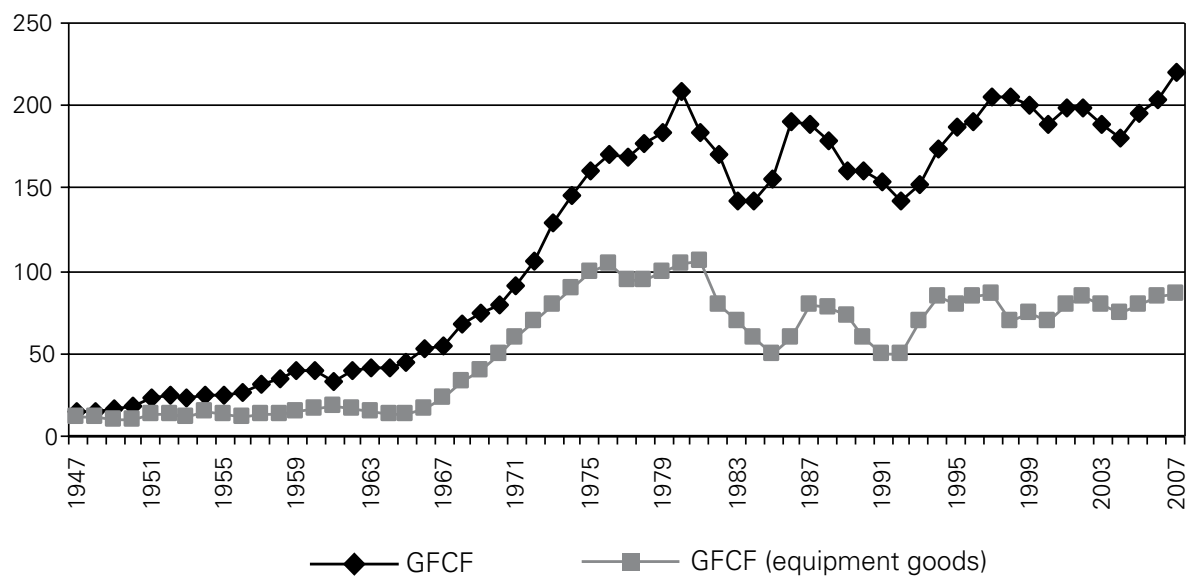

Source: IEDI (2007), graph made by the author. 
Similarly, one of the explanations to the recent decrease of Brazil's inequalities lays on the slowdown of accumulation, and on a stronger use of workforce (relatively to the used capital) than before, particularly in the formal sector. According to the OCDE, the labor demand elasticity to growth has increased from 0,4 in 1996 to 0,9 in 2004. So, the capital productivity keeps rising because there is a substitution of labor for capital: the value-added increases faster than the stock of fixed capital.

The current capital productivity rise is here explained by the slowdown of accumulation. Furthermore, the decrease of this productivity, from 1950 to the 1980s, can be understood as a consequence of a very high investment rate. Because of this investment rate, the stock of fixed capital kept rising and equipment goods were regularly replaced (essentially in order to face up to competition), which weighed on the profit rate while the labour productivity continued to grow.

Here, we concur with Marx's thesis on the falling rate of profit: during the accumulation process, more and more constant capital is used at the expense of variable capital, what leads to increase the organic composition of capital. Actually, in such a situation the capital productivity can only plummet, and the labor one is bound to rise. Nonetheless, the fact remains that with a strong technical progress spread in the whole productive sectors, it is possible that a labor productivity increase can be accompanied by a capital productivity rise. However, such a situation can only be observed during the periods of technological catching-up.

\section{Trajectory “à la Marx”}

Nowadays, it is commonly admitted that since the middle of the 1990 s, the Brazilian rate of profit is slightly rising, although it had not stopped falling during the two precedent decades. Many studies, particularly Miguel Bruno's thesis, try to explain this evolution: they usually focus on the rising weight of finance and on the exploitation rate increase. These important points will be analyzed here, and it will be shown that according to Bruno's thesis, there is no more "Marxist trajectory" in Brazil. However, cannot the rising rate of profit be explained by Marx's theory?

Graph 13: Brazilian rate of profit (1950-2007)

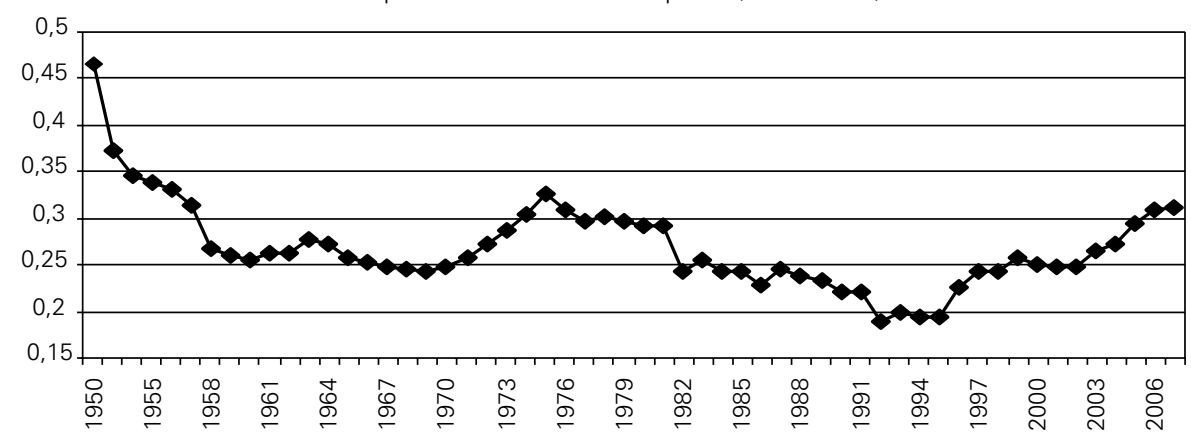

Source: IPEADATA (Rate of profit: (GDP - Stock of wages) / (Stock of fixed capital + Stock of wages)), graph made by the author. 
According to Miguel Bruno (2005), from 1966 to 1978 the Brazilian accumulation was "profit-led" because the rising profit rate led to an investment rate growth, contrary to what happened during the 1990s. What were the causes of this growth? Indeed, the whole catching-up countries experiment such an evolution thanks to the possibility to obtain a capital productivity increase (as Isaac Johsua (2006) recently shows for the postwar Europe). Such a catching-up cannot be restarted by mere technical progress.

In fact, apart from catching-up phases, the productive apparatus is channeled towards a more and more monopolistic structure, particularly in highly capitalistic sectors. As these sectors usually produce production goods, it is unusual for the technical progress obtained by the sector 1 (production goods) to be reflected in the whole productive apparatus. Moreover, a rise of the capital productivity cannot last a long time, because prices are bound to fall in reason of competition. So then, outside of catching-up periods, a rising rate of profit cannot be obtained by a mere technical progress and capital productivity increase.

According to Bruno (2005), the growth of the profit rate between 1968 and 1975 has its roots in the technical progress of the time. This progress leads to a rise of the labor productivity and to a stagnation of the organic composition of capital. For Marx's theory on the falling rate of profit, the rising profit rate lays not only on an increase of the exploitation rate, but it also depends on the capital productivity evolution. Between 1968 and 1975, the growth of the profit rate is linked to an intensive accumulation of capital and to an expansion of labor and capital productivity.

Since the end of the 1970s to the middle of the 1990s, the Brazilian rate of profit has been decreasing (see Graph 13). Miguel Bruno explains this decrease without Marx's thesis because he does not put forward anymore the evolution of the capital productivity. The falling rate of profit would be the result of the precedent intensive accumulation and of the idle capacities engendered by it. Indeed, while the labor and capital productivity strongly increased, the real wages did not follow. The whole stock of wages plummeted from $57 \%$ of the GDP in 1958 to $44 \%$ in 1980 . At the same time, the labor and capital productivity experimented a fall (see Graph 8 and 9).

Graph 14: Idle production capacities in Brazil, in \% of the whole capacities (1970-2007)

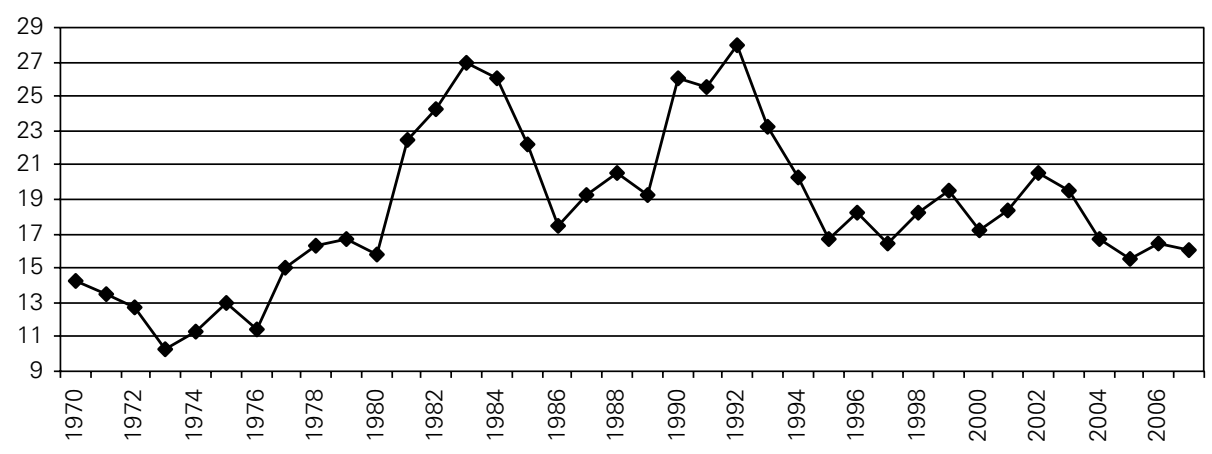

Source: IPEADATA, graph made by the author. 
It is true that there is a growth of idle capacities since 1974 (from $10 \%$ to $27 \%$ in 1983), but according to Bruno, it is the only reason of the falling rate of profit. Admittedly, the period of the "Economic Miracle" (from 1967 to 1974) is characterized by a disconnection between supply and demand because productivity gains are not reflected in wages. These gains only allow to rise the relative surplus-value, and to take advantage of the fall of consumption goods prices (and then of a lesser labor cost). The volume of production rockets meanwhile the real wages remain stable, which induces overproduction and idle capacities. These idle capacities cause a decrease in realized surplus-value, and then weigh on the profit rate. Nevertheless, such phenomena cannot explain alone the pressure exerted on the rate of profit.

Since 1974, the capital productivity experiments a strong fall which is not explained by Bruno. In fact, this fall, corresponding to the end of the catching-up process, plays a large part in the organic composition of capital growth, and then, on the falling rate of profit. It is assumed here that this evolution of the organic composition of capital has its roots in the intensive accumulation process.

Because of competition, the accumulation of capital leads to a substitution of labor by capital, and then to a rise of the constant capital used up in the process at the expense of the variable capital. As capitalism is responsible for a more and more monopolistic production apparatus (particularly in production goods), it is very difficult to obtain a capital productivity growth outside of a catching-up period. So, the equipment goods' prices keep rising since the end of the 1970s (see Graph 11). Nonetheless, the fact remains that Miguel Bruno observes a growth of the Brazilian profit rate since 1994. How to explain such an evolution? In this order, Bruno essentially remains within the framework of the regulationist thought.

He concurs with the regulationist thesis when he analyses the current Brazilian situation. For him, and for the regulationists, the unstable growth experimented by this country is the result of the financialization of its economy. The investment is stagnating because of the financial profits made at the expense of the net profits staying in the hands of "productive capitalists". Like in the Center economies, the profit rate rises in reason of an exploitation rate increase engendered by the growing needs of stockholders. Furthermore, exploitation is reinforced by an unstable and insecure labor market which is a consequence of the slowdown of accumulation and of the unemployment boom. Like in the regulationist thought, here we have a "good productive capitalism" opposed to a "bad finance capitalism".

\section{Rising rate of profit and deindustrialization}

According to Bruno and the French regulationists (like Robert Boyer, 1986), Brazil as well as the Center economies do not follow a trajectory "à la Marx" anymore. In fact, the current rising rate of profit would throw Marx's thesis about the tendency of the rate of profit to fall back into doubt. Specialists of the subject often stress on the word "tendency" in order to explain that, for Marx, the falling rate of profit was not a permanent feature of the capitalist mode of production. However, it is essential to wonder about the different tendencies in the evolution of the profit rate. Can the present growth be explained by The Capital?

In the Regulationist analysis, the capital productivity evolution is only men- 
tioned during the periods of falling rate of profit. Since the end of the 1960s, the growth of the organic composition of capital in the Center economies would have its origins in the capital productivity drop which also leads to the falling rate of profit observed in these countries until the beginning of the 1980s. Then, the financialization of Brazil and Center economies would allow to rise the exploitation and the profit rate. However, the recent evolution of the organic composition of capital is no longer presented as an element of the profit rate. Yet, it is essential to analyze the capital and labor productivity evolution to have a better understanding of the organic composition of capital. And this one is as important as the exploitation rate to measure the rate of profit.

As the Graph 9 beside shows, the capital productivity does not decrease anymore, and even experiments a slight rise since the end of the 1980s (Morandi, 2005). Moreover, the labor productivity is rocketing, after having decreased during the 1980s. Because of the capital productivity growth, the organic composition of capital is rising slower than during the years following the Economic Miracle. From 1985 to 2007, it has increased two times slower than from 1965 to 1985.

It is possible to distinguish two periods. From 1983 to 1994, the stagnation of the organic composition of capital is accompanied with an exploitation rate decrease and then, with a falling profit rate. These two phenomena can be explained by the crisis situation experimented by Brazil during the 1980s, and in particular by its difficulties paying back its external debt. In reason of these financing problems and of the falling rate of profit, the investment rate strongly plummets and equipment goods are not replaced. The volume of production is reduced, but in a lesser extent. Then, the capital productivity stops decreasing, and even begins to rise since 1993. The labor productivity also decreases in reason of the same problems. Furthermore, thanks to social struggles, the productive apparatus maintains a relatively high volume of work (which explains that the stock of wages, in relation to the GDP, keeps rising during the 1980s). In fact, the labor productivity decreases from 1983 to 1994.

From 1994 to now on, the organic composition of capital still stagnates (except from 2002 to 2005 , when it strongly rises) meanwhile the exploitation rate sharply increases. The growing gap between both leads to a growth of the rate of profit. How to explain these divergent evolutions? Indeed, the slight rise of the organic composition is linked to the capital productivity increase: as we have seen before, for the IEDI (2005), since the 1990s, the capital productivity is rising because equipment goods are not replaced in reason of the "relative deindustrialization". Moreover, the labor productivity growth has not so much its origins in the financialization as in this deindustrialization.

According to the Regulationist analysis, financiers' requirements (appearing with high interest rates in Brazil) harm the investment climate, and enterprises have no option but to lay a lot of people off and to push down the wages. Can the financialization of the economy and these increased requirements be responsible for a rising exploitation rate? It is certain that the level of real interest rates is lower today than at the end of the $1980 \mathrm{~s}^{9}$, but the fact remains that the exploitation rate is only

\footnotetext{
${ }^{9}$ In 1990 , the real short-term interest rate reached $21 \%$, versus $8,6 \%$ in 2008.
} 
increasing since 1994 although it had never stopped falling from 1985 to 1994 . So, another explanation has to be found.

Since the middle of the 1990s, Brazil is experimenting a fall of its inequalities the regulationist thesis cannot explain. If the exploitation rise was the result of the financialization, there would be an increase of inequalities opposing rentiers and wage earners. It is the very thesis of Pochmann. However, since the middle of the 1990 s, inequalities are decreasing in this country, mainly in reason of the lesser gap between qualified and unqualified workers (Gaulard, 2008). In fact, the Gini coefficient has decreased from 0,60 in 1994 to 0,55 in 2008 although it had never stopped rising during the precedent decades.

This evolution is the result of the deindustrialization process Brazil is facing with. For the IEDI (2005), the country is confronted with a phase of deindustrialization characterized by a decreasing share of high-tech goods in the national industrial production. Brazil specializes in sectors intensive in natural resources (chemical, metalworking and steel industry, etc.), and more and more neglects traditional sectors (textile, electronics). These sectors intensive in natural resources represented $35,9 \%$ of the industrial production in 1991 , against $45,7 \%$ in 2006 . Then, there is a correlation between the Brazilian inequalities decrease, the deindustrialization process and exploitation growth.

However, it could be argued that it is paradoxical to observe a decrease of inequalities at the same time as the exploitation rate is rising. Actually, the demand of unqualified workers is increasing more than the one of qualified (because of the "relative deindustrialization" described before), which explains the fall of inequalities between work incomes. Because of this new direction of Brazil's industry, the volume of production is increasing faster than during the 1990s: the growth of the GDP reaches $3 \%$ since the beginning of the new millennium against $1,5 \%$ in the 1980 s. There is thus an increase of the exploitation rate not because of the financialization of the economy, but in reason of a more intensive use of unqualified work which is less paid than the qualified one.

In consequence, the rising rate of profit remains within the Marxist framework: for Marx, the accumulation process leads to a falling rate of profit. Today, the Brazilian investment rate is stagnating because of this evolution of the profit rate until the middle of the 1990s, and the slowdown of accumulation has induced a rising rate of profit since 1994. However, this situation could be harmful for the Brazilian economy, because the growth of the profit rate does not represent new incentives for investment anymore, and capitalism cannot survive without technological progress and new investments.

\section{CONCLUSION}

The reasons of the deadlocks Brazil's economy is facing with cannot be found outside the productive apparatus, that is to say in financial sectors. On the contrary, the development of finance allows to deal with these deadlocks by helping curbing the investment rate and then increasing the profit rate. Indeed, since 1994, the capital productivity is expanding, mainly in reason of the relative deindustrializa- 
tion which leads not only to a lesser use of fixed capital in profit of labor but also to a higher exploitation rate. Nevertheless, this deindustrialization could jeopardize Brazil's economic growth as the country is losing its place in world trade relationships. Moreover, today's decreasing prices of raw materials is questioning the relevance of the new direction followed by the Brazilian industry.

\section{REFERENCES}

Bonelli R., Lisboa Bacha E. (2005), "Uma interpretação das causas da desaceleração econômica do Brasil”, Revista de Economia Política, vol. 25, n 3, July-September, pp. 163-189.

Boito Junior A. (2006), “A burguesia no goberno Lula”, in Basualdo M., Arceo E., Neoliberalismo y sectores dominantes, Tendancias globales y experiencias nacionales, Buenos Aires: CLACSO.

Boyer R. (1986), Capitalismes Fin de Siècle, Paris: PUF.

Bresser Pereira L. (2007), Macroeconomia da Estagnação: Crítica da Ortodoxia Convencional no Brasil pós-1994, São Paulo: Editora 34.

Bruno M. (2005), Les Transformations du Régime d'Accumulation au Brésil à la Lumière de la Théorie de la Régulation, Thèse de Doctorat, Paris.

Bruno M. (2007), "Financiarisation et accumulation du capital productif au Brésil”, Revue Tiers Monde, $\mathrm{n}^{\circ} 189$, January-March.

Feu A. (2004a), “Avaliação da produtividade de capital no século XX”, Economia e Energia, n 43, March-April.

Feu A. (2004b), “Evolução do investimento no Brasil”, Economia e Energia, n 46, October-November.

Gaulard M. (2008), Accumulation du Capital et Inégalités: une approche comparée Chine/Brésil, PhD Thesis, Panthéon-Sorbonne, Paris.

Gonçalves R. (2006), “Desestabilização macroeconômica e dominação do capital financeiro no Brasil”, in Basualdo M., Arceo E., Neoliberalismo y Sectores Dominantes, Tendancias Globales y Experiencias Nacionales, Buenos Aires: CLACSO.

Grossman H. (1979), La Ley de Acumulación y del Derrumbe del Sistema Capitalista, México: Siglo Veintiuno editors.

Husson M. (2001), “Années 70: la crise et ses leçons”, in Husson M., Johsua I., Toussaint E., Zerbato M., Crises Structurelles et Financières du Capitalisme au $20^{e}$ siècle, Paris: Syllepse.

IEDI (2005),"Ocorreu uma desindustrializacão no Brasil”, November, www.iedi.org.br.

IEDI (2007), “O problema no preço relativo do investimento fixo no Brasil”, August, www.iedi.org.br.

Johsua I. (2006), Une Trajectoire du Dapital: De la Crise de 1929 à Celle de la Nouvelle Économie, Paris: Editions Syllepse.

Morandi L. (2005), “Estoque e produtividade do capital fixo: Brasil 1950-20034”, Textos Para Discussão $n^{\circ} 174$, Universidade Federal Fluminense, August.

Paes de Barros R., Cury S., Ulyssea G. (2007), “A desigualdade de renda no Brasil encontra-se subestimada? Uma análise comparativa com base na PNAD, na POF e nas contas nacionais”, IPEA, Texto Para Discussão ${ }^{\circ} 1263$, Rio de Janeiro, March.

Palma G. (2006), "Stratégies actives et stratégies passives d'exportation en Amérique Latine et en Asie orientale", Revue Tiers Monde, $\mathrm{n}^{\circ}$ 186, April-June, pp. 249-280.

Pochmann M., Amorim R. (2003), Atlas da Exclusão Social no Brasil, São Paulo: Cortez Editora.

Serra J. (1982), Desenvolvimento Capitalista no Brasil, São Paulo: Editora Brasiliense.

Teixeira Torres Filho E., Pimentel Puga F. (2007), “Investimento na economia brasileira: o caminho do crescimento sustentado", Perspectiva do Investimento 2007-2010, BNDES, June. 